\title{
Isolation, Molecular Characterization and Antimicrobial Resistance Patterns of Four Different Vibrio Species Isolated from Fresh Water Fishes
}

\author{
Y. Suresh, N. Subhashini, Ch. Bindu Kiranmayi*, K. Srinivas, V. Prasastha Ram, \\ G. Chaitanya, B. Swathi Vimala and T. Srinivasa Rao
}
Department of Veterinary Public Health and Epidemiology, NTR College of Veterinary Science, Gannavaram, Sri Venkateswara Veterinary University (SVVU), Tirupati-517 502, Andhra Pradesh, India

*Corresponding author

\section{A B S T R A C T}

Keywords

Vibrio vulnificus, $V$. parahaemolyticus, $V$. alginolyticus, $V$. cholerae, Freshwater fishes, Extended Spectrum BetaLactamases

Article Info

Accepted:

24 June 2018

Available Online:

10 July 2018
Vibrio species are the major food borne pathogens commonly associated with aquatic food poisonings and lead to food-borne outbreaks. In this present study, out of 105 fresh water fish (Catlacatla) samples collected, $87(82.85 \%)$ were found positive for Vibrio species. Out of $87,6(6.9 \%), 2(2.3 \%), 4(4.6 \%)$ and $3(3.45 \%)$ isolates were found to be $V$. parahaemolyticus and $V$. vulnificus, $V$. alginolyticus and $V$. cholerae respectively by mPCR. The 15 different Vibrio species were subjected to antibiogram studies including ESBL detection. Antibiotics like ampicillin, penicillin, gentamycin, amikacin, tetracycline, ceftazidime, streptomycin and co-trimoxazole were used for antibiogram profile. Out of 15 isolates, 5 isolates were found positive for ESBLs by both phenotypic and molecular methods. Out of 5ESBL (only TEM gene) positive isolates, 2 (33.33\%), 1 (50\%), 1 (25\%) and $1(33.33 \%)$ were from $V$. parahaemolyticus, V. vulnificus, V. alginolyticus and $V$. cholera respectively by $\mathrm{MPCR}$.

\section{Introduction}

Members of genus Vibrio are defined as gram negative, asporogenous rods that are straight or have a single rigid curve and are motile with a single polar flagellum when grown in liquid medium and they are widely acknowledged as one of the most important waterborne pathogens causing gastrointestinal disorders (Kaysner and De Paola, 2004). Vibrio species will be present as contaminants of raw or undercooked sea food (Gopal et al.,
2005; Di Pinto et al., 2008; Luan et al., 2008) and consumption of such foods may lead to acute gastroenteritis including diarrhea, headache, vomiting, nausea and fever (Apun et al., 1999; Vongxay et al., 2008; Yang et al., 2008). Igbinosa and Okoh (2008) opined that Vibrio spp. are highly prevalent in marine and aquatic environments and is occasionally associated with outbreaks concerning man. The chief route of transmission is by consumption of food and water contaminated with human faeces or sewage, raw fish and 
other sea food. Other route of transmission is entry through broken skin when exposed to aquatic environments and marine organisms. In high prevalence areas, chances of cross contamination of foods are also high. In developing countries, massive outbreaks of $V$. cholerae occur mainly via faeco-oral transmission due to poor sanitation (Faruque et al., 1998; Kaper et al., 1995). V. parahaemolyticus, $V$. vulnificus and $V$. cholera have been recognized as important food-borne pathogens, which can cause human diseases (Su and Liu, 2007; Zhang and Austin, 2005). $V$. alginolyticus has been categorized as a human pathogen since 1979 and it may result in endophthalmitis, otitis media and food poisoning in infected patients (Ardic and Ozyurt, 2004; Li et al., 2009; Schmidt et al., 1979). The opportunistic pathogen $V$. vulnificus can cause gastroenteritis, septicemia and wound infections, with high fatality rates in immuno-compromised individuals and those with chronic liver disease (Daniels and Shafaie, 2000; Oliver and Kaper, 2001). Antimicrobial resistance is one of the most important public health problems that directly relates to disease management and control (Ansari and Raissy, 2010). Recently higher frequency of multidrug-resistant Vibrio has been reported (Ansari and Raisy, 2010; Okoh and Igbinosa, 2010). Production of extendedspectrum $\beta$-lactamases (ESBLs) is a significant resistance-mechanism which is a serious threat to the currently available antibiotic armory (Shaikh et al., 2015). So the present study was carried with an objective of studying the prevalence and antibiogram of Vibrio speicies of fresh water fish in and around Vijayawada, Andhra Pradesh, India.

\section{Materials and Methods}

\section{Standard control and primers}

Pure cultures of Vibrio parahaemolyticus and V.vulnificus obtained from MTCC,
Chandigarh were used as positive controls. Oligonucleotide primers were custom synthesized from $\mathrm{M} / \mathrm{s}$. Bioserve Biotechnologies Pvt. Ltd. (Hyderabad).

\section{Sample collection}

A total of 105 fresh water fish (Catla catla) samples were collected from fish markets in and around Vijayawada, Andhra Pradesh. The samples (10grams) were homogenized with $90 \mathrm{ml}$ of Alkaline Peptone Water (APW) with $3 \% \mathrm{NaCl}$ and incubated at $37^{\circ} \mathrm{C}$ for 24 hours. The enriched cultures were streaked on Thiosulphate Citrate Bile salt Sucrose (TCBS) agar and plates were incubated at $37^{\circ} \mathrm{C}$ for 24 hours. On TCBS, V. parahaemolyticus and $V$. vulnificus produce green coloured colonies where as $V$. cholerae and $V$. alginolyticus produce yellow colored colonies. The respective colonies were further confirmed by biochemical tests and multiplex-PCR (mPCR).

\section{Antibiogram and $\beta$-lactamase production}

Antibiogram of Vibrio species was carried out against 8 different antibiotics like Ampicillin, Gentamycin, Amikacin, Tetracycline, Ceftazidime, Penicillin, Streptomycin and Cotrimoxazole by Kirby Bauer disc diffusion method on Muller Hinton agar (Bauer et al., 1966). Direct colony suspension of each isolate was made in PBS (pH 7.4) and the turbidity was adjusted to $0.5 \mathrm{McFarland}$ units (equivalent to an approximate cell density of $1.5 \times 108 \mathrm{CFU} / \mathrm{ml})$. The diameter of inhibition zones was measured and susceptibility patterns of Vibrio species were interpreted according to Clinical and Laboratory Standards Institute (CLSI) guidelines (CLSI, 2014).

Detection of ESBL production was done phenotypically by Phenotypic Screening Test (PST) and Phenotypic Confirmation Test (PCT) as recommended by CLSI (2014) 
guidelines.PST was carried out using four indicator $\beta$-lactam antibiotics: Cefotaxime (CTX, $30 \mu \mathrm{g}$ ), Ceftazidime (CAZ, $30 \mu \mathrm{g}$ ), Ceftriaxone (CTR, $30 \mu \mathrm{g}$ ) and Aztreonam (AT, $30 \mu \mathrm{g}$ ). Resistance to at least one of the four antibiotics was considered to be positive PST for ESBL production. The positive PST isolates were then subjected to PCT by combination disc method using three pairs of antibiotic discs: ceftazidime (CAZ, $30 \mu \mathrm{g})$, ceftazidime plus clavulanic acid (CAC, 30/10 $\mu \mathrm{g})$, cefotaxime (CTX, $30 \mu \mathrm{g}$ ), cefotaxime plus clavulanic acid (CEC, 30/10 $\mu \mathrm{g}$ ) and ceftriaxone (CTR, $30 \mu \mathrm{g}$ ), ceftriaxone plus sulbactam (CIS, 30/10 $\mu \mathrm{g}$ ). ESBL production was confirmed when zone diameter around the combination discs was more than or equal to 5 $\mathrm{mm}$ when compared to discs containing respective cephalosporin alone (Drieux et al., 2008).

\section{Multiplex PCR (mPCR)}

DNA was extracted from all the Vibrio isolates by using boiling and snap chilling (Swetha et al., 2015) with slight modifications. $1.5 \mathrm{ml}$ of enriched broths were taken into micro centrifuge tubes and centrifuged at $8000 \mathrm{rpm}$ for $10 \mathrm{~min}$. Supernatant was discarded, $50 \mu \mathrm{l}$ of nuclease free water was added and placed in boiling water bath at $100^{\circ} \mathrm{C}$ for $10 \mathrm{~min}$. Immediately snap chilled for $10 \mathrm{~min}$ and centrifuged at $10,000 \mathrm{rpm}$ for $5 \mathrm{~min}$. The supernatant was taken as template and subjected to different mPCRs and the PCR products were subjected to gel electrophoresis using $1.5 \%$ agarose with ethidium bromide as fluorescent dye and visualized using Gel Documentation unit (BIORAD, USA).

\section{MPCR for Vibrio species identification}

It was done by targeting genus and species specific genes (Table 1). PCR assay was optimized in $25 \mu \mathrm{l}$ reaction mixture containing
$2 \mu 1$ of DNA template, $12.5 \mu 1$ of $2 x$ master mix (Go Taq Green Master Mix, Promega), $0.5 \mu 1$ each of forward and reverse primers (10 $\mathrm{pmol} / \mu \mathrm{l}$ ) and the rest of the volume is made by adding nuclease free water, under standardized cycling conditions: initial denaturation at $94^{\circ} \mathrm{C}$ for $3 \mathrm{~min} ; 30$ cycles of $94^{\circ} \mathrm{C}$ for $30 \mathrm{~s}, 60^{\circ} \mathrm{C}$ for $30 \mathrm{~s}$ and $72^{\circ} \mathrm{C}$ for $120 \mathrm{sec}$ and a final elongation step at $72^{\circ} \mathrm{C}$ for $10 \mathrm{~min}$.

\section{MPCR for ESBL genes}

DNA from all the PCT positive Vibrio isolates were subjected to two MPCR assays for detection of ESBL genes (Table 2). PCR assays were optimized in $25 \mu 1$ reaction mixture containing $2 \mu \mathrm{l}$ of DNA template, $12.5 \mu 1$ of $2 \mathrm{x}$ master mix (Go Taq Green Master Mix, Promega), $0.5 \mu 1$ each of forward and reverse primers $(10 \mathrm{pmol} / \mu \mathrm{l})$ and the rest of the volume is made by adding nuclease free water, under standardized cycling conditions: initial denaturation at $94^{\circ} \mathrm{C}$ for $10 \mathrm{~min} ; 30$ cycles of $94^{\circ} \mathrm{C}$ for $40 \mathrm{~s}, 60^{\circ} \mathrm{C}$ for $40 \mathrm{~s}$ and $72^{\circ} \mathrm{C}$ for $1 \mathrm{~min}$ and a final elongation step at $72^{\circ} \mathrm{C}$ for $7 \mathrm{~min}$.

\section{Results and Discussion}

Out of 105 fresh water fish samples, 87 were found positive for Vibrio species. Out of 87 Vibrio species, $V$. parahaemolyticus was found to be more prevalent followed by $V$. alginolyticus, $V$. cholerae and $V$. vulnificus (Fig. 1). In the present study, the overall occurrence rate of Vibrio spp. was found to be $82.85 \%$ compared to $98.67 \%$ and $27.5 \%$ as reported by Noorlis et al., (2011) and El-Hady et al., (2015) respectively.

In the present study, we found that $6.9 \%$ (6/87) of the Vibrio isolates were belonging to $V$. parahaemolyticus whereas high prevalence rates of $24 \%, 28.6 \%$ and $75.9 \%$ of $V$. parahaemolyticus were reported by Noorlis $e t$ al., (2011), Nelapati and Krishnaiah (2010) 
and Anjay et al., (2014) respectively. Adebayo-Tayo et al., (2011) reported a prevalence rate of $2.5 \% \mathrm{~V}$. vulnificus which is in accordance to the present study of $2.3 \%$ (2/87) whereas Thampuran and Surendran (1998) reported a high occurrence upto a level of $16.6 \%$. In our study, $4.6 \%$ (4/87) of isolates were found to be $V$. alginolyticus which was in agreement with Adebayo-Tayo (2011).The occurrence rate of $V$. cholerae was found to be $3.45 \%$ (3/87) which was less when compared to $6 \%$ reported by Traore et al., (2014). The variations in occurrence of different species of Vibrio may be due to level of salinity, geographic, seasonal variations and isolation procedures followed (Kaneko and Clowell, 1975 and Deepanjali et al., 2005).

Table.1 Oligonucleotide primers used for detection of Vibrio species by mPCR

\begin{tabular}{|c|c|c|c|}
\hline $\begin{array}{l}\text { Target genes and } \\
\text { species }\end{array}$ & Primer sequence & $\begin{array}{l}\text { Product } \\
\text { size (bp) }\end{array}$ & Reference \\
\hline $\begin{array}{l}\text { omp } W \\
\text { V. cholerae }\end{array}$ & $\begin{array}{l}\text { CACCAAGAAGGTGACTTTATTGTG } \\
\text { CGTTAGCAGCAAGTCCCCAT }\end{array}$ & 427 & Nandi et al., 2000 \\
\hline $\begin{array}{l}\text { gyrB } \\
\text { V. alginolyticus }\end{array}$ & $\begin{array}{l}\text { GAGAACCCGACAGAAGCGAAG } \\
\text { CCTAGTGCGGTGATCAGTGTTG }\end{array}$ & 337 & Zhou et al., 2007 \\
\hline $\begin{array}{l}\text { collagenase } \\
V . \text { parahaemolyticus }\end{array}$ & $\begin{array}{l}\text { GAAAGTTGAACATCATCAGCACGA } \\
\text { GGTCAGAATCAAACGCCG }\end{array}$ & 271 & $\begin{array}{l}\text { Di Pinto et al., } \\
2005\end{array}$ \\
\hline $\begin{array}{l}\text { vvhA } \\
\text { V. vulnificus }\end{array}$ & $\begin{array}{l}\text { TTCCAACTTCAAACCGAACTATGA } \\
\text { ATTCCAGTCGATGCGAATACGTTG }\end{array}$ & 205 & $\begin{array}{l}\text { Panicker et al., } \\
2004\end{array}$ \\
\hline $\begin{array}{l}\text { 16S rRNA (Genus } \\
\text { specific) }\end{array}$ & $\begin{array}{l}\text { CCTGGTAGTCCACGCCGTAA } \\
\text { CGAATTAAACCACATGCTCCA }\end{array}$ & 168 & Wei et al., 2014 \\
\hline
\end{tabular}

Table.2 Oligonucleotide primers used for detection of ESBLgenes (Dallenne et al., 2010)

\begin{tabular}{|l|l|l|c|}
\hline Primer & $\begin{array}{c}\beta \text {-lactamase }(\mathrm{s}) \\
\text { targeted }\end{array}$ & \multicolumn{1}{|c|}{ Primer sequence } & $\begin{array}{c}\text { Amplicon } \\
\text { size (bp) }\end{array}$ \\
\hline blaTEM & TEM-1\&2 & $\begin{array}{l}\text { 1st mPCR } \\
\text { CATTTCCGTGTCGCCCTTATTC } \\
\text { CGTCATCCATAGTTGCCTGAC }\end{array}$ & 800 \\
\hline blaSHV & SHV-1 & $\begin{array}{l}\text { AGCCGCTTGAGCAAATTAAAC } \\
\text { ATCCCGCAGATAAATCACCAC }\end{array}$ & 713 \\
\hline blaOXA & OXA-1,4\&30 & $\begin{array}{l}\text { GGCACCAGATTCAACTTCAAG } \\
\text { GACCCCAAGTTCCTGTAAGT }\end{array}$ & 564 \\
\hline $\begin{array}{l}\text { blaCTX- } \\
\text { M1 }\end{array}$ & $\begin{array}{l}\text { CTX-M-1, CTX- } \\
\text { M-1 and CTX- }\end{array}$ & $\begin{array}{l}\text { TTAGGAARTGTGCCGCTGYAb } \\
\text { CGATATCGTTGGTGGTRCATb }\end{array}$ & 688 \\
\hline $\begin{array}{l}\text { blaCTX- } \\
\text { M2 }\end{array}$ & CTX-M-2 & $\begin{array}{l}\text { CGTTAACGGCACGATGAC } \\
\text { CGATATCGTTGGTGGTRCCATb }\end{array}$ & 404 \\
\hline $\begin{array}{l}\text { blaCTX- } \\
\text { M9 }\end{array}$ & $\begin{array}{l}\text { CTX-M-9 and } \\
\text { CTX-M-14 }\end{array}$ & $\begin{array}{l}\text { TCAAGCCTGCCGATCTGGT } \\
\text { TGATTCTCGCCGCTGAAG }\end{array}$ & 561 \\
\hline
\end{tabular}


Table.3 Details of Antibiotic resistance of Vibrio species by phenotypic method

\begin{tabular}{|c|c|c|c|c|c|}
\hline Antibiotics & $\begin{array}{c}\text { V. parahaemolyticus } \\
\text { (6) }\end{array}$ & $\begin{array}{l}\text { V. vulinificus } \\
\text { (2) }\end{array}$ & $\begin{array}{c}V . \text { alginolyticus } \\
\text { (4) }\end{array}$ & $\begin{array}{c}\text { V. cholerae } \\
\text { (3) }\end{array}$ & Total \\
\hline $\begin{array}{l}\text { Ampicillin } \\
\text { (AMP-10 } \mu \mathrm{g})\end{array}$ & 5 & 2 & 4 & 3 & $14(93.38 \%)$ \\
\hline $\begin{array}{l}\text { Gentamicin } \\
(\mathrm{GEN}-30 \mu \mathrm{g})\end{array}$ & 5 & 2 & 3 & 2 & $12(80 \%)$ \\
\hline $\begin{array}{l}\text { Amikacin } \\
(\mathrm{AK}-30 \mu \mathrm{g})\end{array}$ & 4 & 1 & 3 & 2 & $10(66.66 \%)$ \\
\hline $\begin{array}{l}\text { Tetracycline } \\
(\mathrm{TE}-30 \mu \mathrm{g})\end{array}$ & 2 & - & 2 & 1 & $5(33.33 \%)$ \\
\hline $\begin{array}{l}\text { Ceftazidime } \\
(\mathrm{CAZ}-30 \mu \mathrm{g})\end{array}$ & 5 & 2 & 3 & 2 & $12(80 \%)$ \\
\hline $\begin{array}{l}\text { Penicillin } \\
\text { (P-10units) }\end{array}$ & 4 & 1 & 2 & 2 & $9(60 \%)$ \\
\hline $\begin{array}{l}\text { Streptomycin } \\
\quad(\mathrm{S}-10 \mu \mathrm{g})\end{array}$ & 1 & - & - & - & $1(6.66 \%)$ \\
\hline $\begin{array}{c}\text { Co- } \\
\text { trimoxazole } \\
(\mathrm{COT}-25 \mu \mathrm{g})\end{array}$ & - & - & - & - & 0 \\
\hline
\end{tabular}

Fig.1 Agarose gel electrophoresis of amplified DNA of Vibrio species by m-PCR

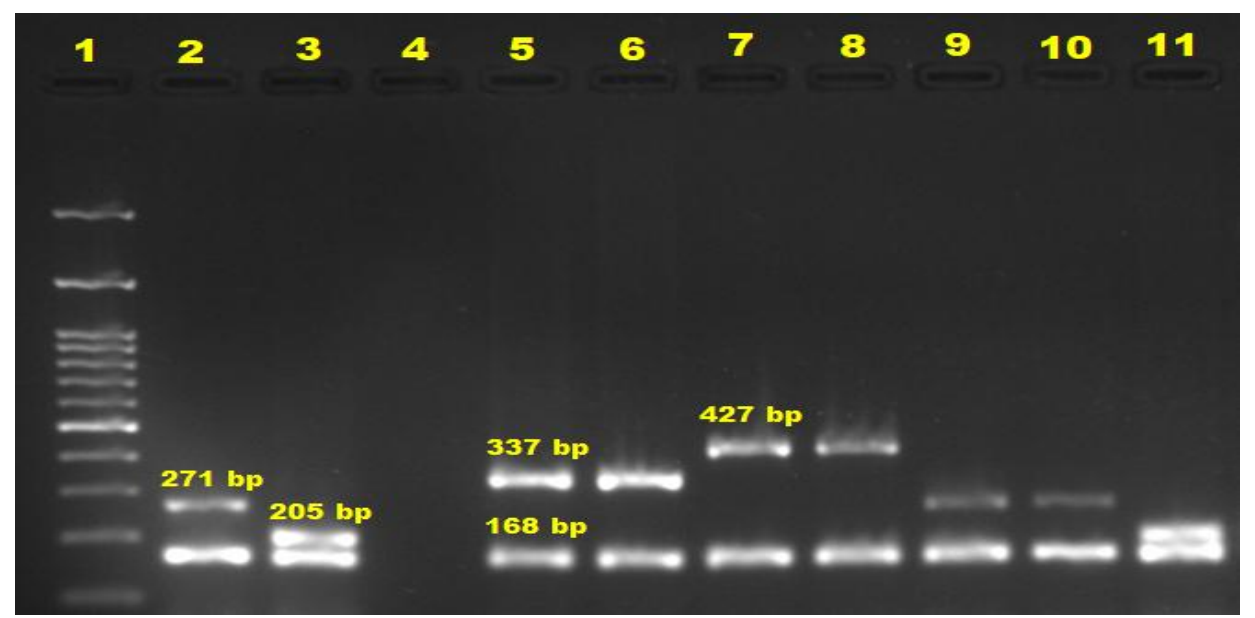

Lane 1: 100 bp DNA ladder

Lane 2: Positive control of V. parahaemolyticus (MTCC 451)

Lane 3: Positive control of V.vulnificus (MTCC 1145)

Lane 4: Negative control

Lane 5\&6: Sample showing V.alginolyticus

Lane 7 \& 8: Sample showing Vibrio cholerae

Lane 9\&10: Sample showing Vibrio parahaemolyticus

Lane 11: Sample showing Vibrio vulnificus

Lane 2-11 except 4 are showing genus specific gene at 168bp 
Fig.2 Agarose Gel Electrophoresis of $b l a_{\mathrm{TEM}}$ gene by m-PCR

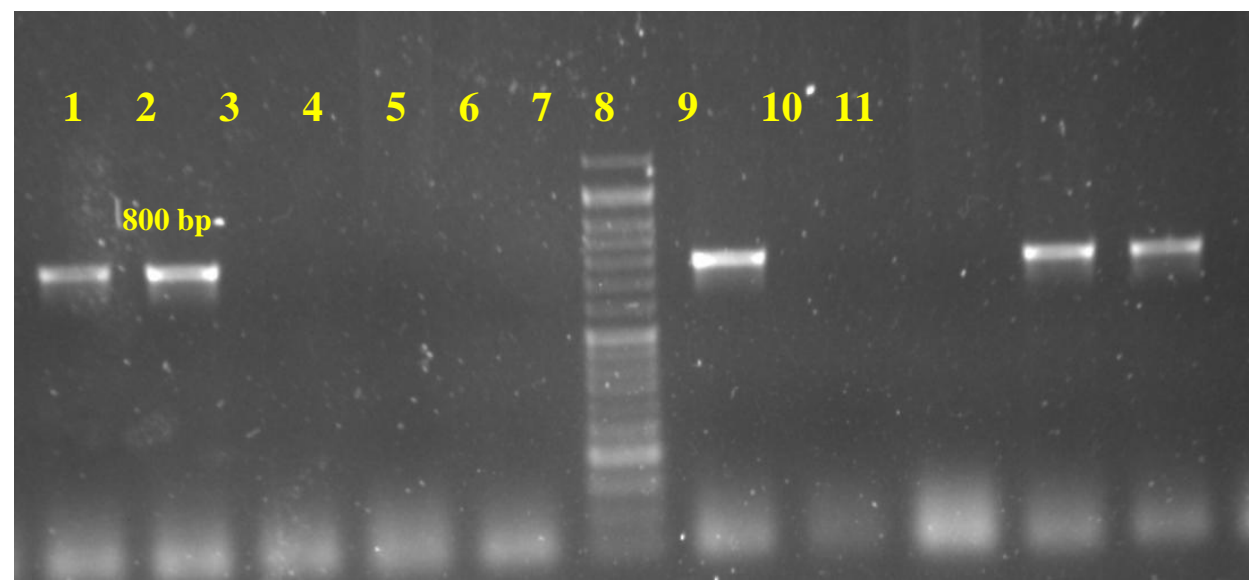

Lane 1, 2, 10 and 11: Samples positive for $b a_{\mathrm{TEM}}$ gene

Lane 3, 4, 5 and 9: Samples negative for $b l a_{\mathrm{TEM}}$ gene

Lane 6: 50 bp DNA ladder

Lane 7: Positive control for $b l a_{\mathrm{TEM}}$ gene

Lane 8: Negative control

Out of 15 Vibrio isolates, highest resistance was recorded against ampicillin followed by gentamicin, ceftazidime, amikacin, penicillin, tetracycline and streptomycin. All of the isolates were found sensitive to cotrimoxazole (Table 3). The resistance patterns of different Vibrio isolates in this study were in accordance with the reports of Raissy et al., (2012), Ansari and Raissy (2010) and Okoh and Igbinosa (2010).

Out of 15 isolates, 5 isolates were found positive for ESBLs i.e. 2 (33.33\%), $1(50 \%)$, $1(25 \%)$ and $1(33.33 \%)$ were from $V$. parahaemolyticus, $\quad V . \quad$ vulnificus, $\quad V$. alginolyticus and $V$. cholerae respectively by both phenotypic and molecular methods. All 5 isolates showed presence of only $b l a_{\text {TEM }}$ gene and none of the isolates were positive for bla $_{\mathrm{OXA}}, \quad b l a_{\mathrm{SHV}}, \quad b l a_{\mathrm{CTX}-\mathrm{M} 1}, \quad b l a_{\mathrm{CTX}-\mathrm{M} 2}$ and

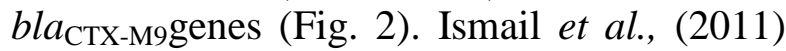
reported presence of TEM-63 gene in all the selected 10 isolates of $V$. cholera $\mathrm{O} 1$ coinciding with that of ceftazidime MIC of 64 $\mu \mathrm{g} / \mathrm{ml}$. Petroni et al., (2002) analysed 28 isolates of $V$. choleae $\mathrm{O} 1$ biotype $\mathrm{E} 1$ for presence of ESBLs by susceptibility analysis, isoelectric focusing, PCR-based RFLP and reported that CTX-M type enzymes were identified in 3 isolates and TEM-1 like enzyme in one isolate.

\section{References}

Adebayo-Tayo, B. C., Okonko, I. O., Esen, N. N., Odu, N. N., Onoh, C. C. and Igwiloh, N. J. P. 2011. Incidence of Potentially Pathogenic Vibrio spp. in Fresh Seafood from Itu Creek in Uyo, Akwalbom State, Nigeria. World Applied Sciences Journal. 15(7): 985991.

Anjay Das, S.C., Kumar, A., Kaushik, P. and Kurmi, B. 2014. Occurrence of Vibrio parahaemolyticus in marine fish and shell fish, Indian journal of geomarine Sciences. 43(5):887-890.

Ansari, M. and Raissy, M. 2010. In vitro susceptibility of commonly used antibiotics against Vibrio spp. isolated from Lobster (Panulirushomarus). African Journal of Microbiology 
Research. 4(23):2629- 2631.

Apun, K., Asiah, M. Y. and Jugang, K. 1999. Distribution of bacteria in tropical freshwater fish and ponds. International Journal of Environmental Health Research 9: 285-292.

Ardic, N. and Ozyurt, M. 2004. Case report: Otitis due to Vibrio alginolyticus. Mikrobiyol Bul. 38(1-2):145-148.

Bauer, A.W., Kirby, W.M.M., Sherris, J.C. and Turck, M. 1966. Antibiotic susceptibility testing by a standardized single disk method. Am. J. Clin. Pathol. 45:493.

CLSI (2014). Clinical and Laboratory Standards Institute. Performance Standards for Antimicrobial Susceptibility Testing: Twenty-fourth Informational Supplement. M100-S24. Wayne, PA, USA.

Dallenne, C., Da Costa, A., Decre, Favier, C. and Arlet, G. 2010. Development of a set of multiplex PCR assays for the detection of genes encoding important $\beta$-lactamases in Enterobacteriaceae. Journal of Antimicrobial Chemotherapy. 65: 490-495.

Daniels N. A. and Shafaie A. 2000. A review of pathogenic Vibrio infections for clinicians. Infect Med. 17:665-685.

Deepanjali, A., Kumar, H. S., Karunasagar, I. and Karunasagar, I. 2005. Seasonal variation in abundance of total and pathogenic $V$. parahemolyticus in oyster along the southwest coast of India. Appl. Environ. Microbiol.71:3575-3580

Di Pinto, A., Ciccarese, G., Tantillo, G., Catalano, D., Forte, V.T. 2005. A collagenase-targeted multiplex PCR assay for identification of Vibrio alginolyticus, Vibrio cholera, and Vibrio parahaemolyticus. J Food Prot. 68(1):150-153.

Di Pinto, A., Ciccarese, G. De Carota, R., Novello, L. and Terio, V. 2008.
Detection of pathogenic Vibrio parahaemolyticus in southern Italian shell fish. Food Control. 19: 10371041.

Drieux, L., Brosier, F., Sougakoff, W. and Jarlier, V. 2008. Phenotypic detection of extended spectrum beta- lactamases production in Enterobacteriaceae. Review and bench guide. Clin Microbiol Infect. 14:90-103.

El-Hady M. A., El-KatibNahla, R. and Essam S. Abdei-Aziz. 2015. Microbiological studies on Vibrio species isolated from some cultured fishes. Animal Health Research Journal. 3(1):12-19.

Faruque, S. M., Albert, M. J., and Mekalanos, J. J. 1998. Epidemiology, genetics, and ecology of toxigenic Vibrio cholerae. Microbiology and Molecular Biology Reviews. 62: 1301-1314.

Gopal, S., Otta, S. K., Karunasagar, I., Nishibuchi, M. and Karunasagar, I. 2005. The occurrence of Vibrio species in tropical shrimp culture environments, implications for food safety. International of Food Microbiology. 102: 151-159.

Igbinosa, E. O. and Okoh, A.I. 2008. Emerging Vibrio species: An unending threat to public health in developing countries. Research in Microbiology. 159: 495-506.

Ismail, H., Smith, A.M., Sooka, A. and Keddy, K. H. 2011. Genetic Characterization of MultidrugResistant, Extended-Spectrum- $\beta$ Lactamase-Producing Vibrio cholerae O1 Outbreak Strains, Mpumalanga, South Africa. Journal of Clinical Microbiology. 2976-2979.

Kaneko, T. and Colwell, R. R. 1975. Incidence of Vibrio parahemolyticus in Chesapeake Bay.Appl. Microbiol. 30 (2): 251-257.

Kaper, J. B., Morris, J. G., Jr., and Levine, M. M. 1995. Cholera. Clinical 
Microbiology Reviews. 8:48-86

Kaysner, C. and De Paola, A. J. 2004. U.S. Food and Drug Administration. Bacteriological Analytical Manual. Methods for specific pathogens. Chapter 9 Vibrio.

Li, X.C., Xiang, Z.Y., Xu, X.M., Yan, W.H. and Ma, J.M. 2009. Endophthalmitis caused by Vibrio alginolyticus. J Clin Microbiol. 47(10):3379-3381.

Luan, X., Chen, J., Liu, Y., Li, Y., Jia, J., Liu, R. and Zhang, X. H. 2008. Rapid quantitative detection of Vibrio parahaemolyticus in seafood by MPNPCR. Current Microbiology. 57: 218221.

Nandi, B., Nandy, R.K., Mukhopadhyay, S., Nair, G.B., Shimada, T. and Ghose, A.C. 2000. Rapid method for speciesspecific identification of Vibrio cholerae using primers targeted to the gene of outer membrane protein ompW. J Clin Microbiol. 38(11):4145-4151.

Nelapati, S. and Krishnaiah, N. 2010. Detection of total and pathogenic Vibrio parahaemolyticus by Polymerase chain reaction using toxR, $t d h$ and trh genes. Veterinary World. 3(6): 268-271.

Noorils, A., Ghazali, F. M., Cheah, Y. K., Zainazor, T., Ponniah, J., Tunung, R., Tang, J. Y. H., Nishiguchi, Y. and Son, R. 2011. Prevalence and quantification of Vibrio species and Vibrio paraheamolyticus. International Food Reaearch Journal. 18:689-695.

Okoh, A. I. and Igbinosa, E. O., 2010. Antibiotic susceptibility profiles ofsome Vibrio strains isolated fromwastewater final effluents in a ruralcommunity of the Eastern CapeProvince of South Africa. BMC Microbiology. 10(143): 1-6.

Oliver, J.D. and Kaper, J. 2001. Vibrio species. In: Doyle M.P., et al., (Eds.),
Food Microbiology: Fundamentals and Frontiers. 263-300.

Panicker, G., Myers, M.L. and Bej, A.K. 2004. Rapid detection of Vibrio vulnificus in shellfish and Gulf of Mexico water by real-time PCR. Appl Environ Microbiol. 70(1): 498-507.

Petroni, A., Corso, A., Melano. A., Cacace, M. L., Bru, A.M. Rossi A and Galas, M. 2002. Plasmidic ExtendedSpectrum- $\beta$-Lactamases in Vibrio cholerae $\mathrm{O} 1 \mathrm{El}$ Tor Isolates in Argentina. Antimicrobial agents and chemotherapy. 1462-1468.

Raisy, M., Moumeni, M., Ansari, M. and Rahimi, E. 2012. Antibiotic resistance pattern of some Vibrio strains isolated from seafood. Irani Journal of Fisheries Science. 11(3):618-626.

Schmidt, U., Chmel, H. and Cobbs, C.1979. Vibrio alginolyticus infections in humans. J. Clin Microbiol. 10(5):666668.

Shaikh, S., Fatima, J., Shakil, S., Rizvi, S.M.D. and Kamal, M.A. 2015. Antibiotic resistance and extended spectrum beta-lactamases: Types, epidemiology and treatment. Saudi Journal of Biological Sciences. 22:90101.

Su, Y. C. and Liu, C. C. 2007. Vibrio parahaemolyticus: a concern of seafood safety. Food Microbiol. 24(6):549-58.

Swetha, C.S., Babu, A.J., Rao, T.M. and Kumar, E. 2015. Evaluation of various selective and non selective broths for detection of Listeria monocytogenes in pork and for PCR compatibility. International Journal of Advanced Research. 3(3): 316-327.

Thampuran, N. and Surendran, P. K. 1998.Occurrence and distribution of Vibrio vulnificus in tropical fish and shellfish from Cochin (India). Lett Appl Microbiol. 26(2): 110-112. 
Traore, O., Martikainen, O., Siitonen, A., TraorE, A. S., Barro, N. and Haukka, K. 2014. Occurrence of Vibrio cholerae in fish and water from a reservoir and a neighbouring channel in Ouagadougou, Burkina Faso. J Infect DevCtries. 8(10):1334- 1338.

Vongxay, K., Wang, S., Zhang, X., Wu, B., Hu, H.,Pan, Z., Chen, S. and Fang, W. 2008. Pathogenetic characterization of Vibrio parahaermolyticus isolates from clinical and seafood sources. International Journal of Food Microbiology. 126: 71-75.

Wei, S., Zhao, H., Xian Y., Hussain, M. A. and Wu, X. 2014. Multiplex PCR assays for the detection of Vibrio alginolyticus, Vibrio parahaemolyticus, Vibrio vulnificus, and Vibrio cholerae with an internal amplification control. Diagnostic Microbiology and Infectious Disease. Yang, Z., Jiao, X., Zhou, X., Cao, G., Fang, $\mathrm{W}$. and $\mathrm{Gu}, \mathrm{R}$. 2008. Isolation and molecular characterization of Vibrio parahaemolyticus from fresh, lowtemperature preserved, dried and salted seafood products in two coastal areas of eastern China. International of Food Microbiology. 125: 279-285.

Zhang, X. H. and Austin B. 2005. Haemolysins in Vibrio species. J Appl Microbiol. 98(5): 1011-1109.

Zhou, S., Hou, Z., Li, N. and Qin, Q. 2007. Development of a SYBR Green I realtime PCR for quantitative detection of Vibrio alginolyticus in seawater and seafood. J Appl Microbiol. 103 (5):1897-1906.

\section{How to cite this article:}

Suresh, Y., N. Subhashini, Ch. Bindu Kiranmayi, K. Srinivas, V. Prasastha Ram, G. Chaitanya, B. Swathi Vimala and Srinivasa Rao, T. 2018. Isolation, Molecular Characterization and Antimicrobial Resistance Patterns of Four Different Vibrio species Isolated from Fresh Water Fishes. Int.J.Curr.Microbiol.App.Sci. 7(07): 3080-3088.

doi: https://doi.org/10.20546/ijcmas.2018.707.359 